\title{
INCITACIÓN DEL GESTO. TEATRO E HISTORIA EN MÁSCARAS, DE LEONARDO PADURA FUENTES
}

\author{
POR \\ LouRdes DÁvila \\ New York University
}

No tendría el teatro ingredientes tan complejos, tan aleatorios, a no ser porque anuda la eternidad, el instante y el tiempo. Y su destino sería:

-la elucidación del instante por un encuentro con lo eterno;

-la orientación en el tiempo por las secuelas de este encuentro.

Alain Badiou, Rapsodia para el teatro

Máscaras (1997), la tercera novela de la tetralogía policial de Mario Conde, trabaja su relación con Virgilio Piñera y su obra a partir del exceso. El primer epígrafe de la obra es una cita del tercer acto de Electra Garrigó (1948), y finaliza con una clave demasiado obvia, que plantea una equivalencia entre el hacer político y el espectador político en la Cuba pre-revolucionaria y la Cuba pos-revolucionaria: "Se trata, no lo olvides, de una ciudad en la que todo el mundo quiere ser engañado" (11). El crimen es perpetrado en contra del homosexual Alexis Arayán Rodríguez, quien realiza su único acto de travestismo el 6 de agosto, día en que se celebra la transfiguración de Cristo, al vestirse de Electra Garrigó y provocar su propio asesinato a manos de su padre en el bosque de La Habana. Obtiene su vestuario del escritor y director Alberto Marqués (un "Virgilio Piñera" que es y no es él) quien, a principio de los años setentas, fue parametrado mientras dirigía una Electra Garrigó travestí. Y, por si fuera poco, el policía Mario Conde recibe de Marqués una clave esencial para el travestismo de la intriga cuando éste le entrega a Conde la hoja del Evangelio de San Mateo que relata el acto de la transfiguración y le informa que "estaba donde debía estar: dentro del Teatro completo de Virgilio Piñera que tengo en mis estantes" (162), texto en cuya introducción Piñera mismo alude al colapsarse del espacio teatral y el espacio político 
público y reubica la lectura de su Electra Garrigó, escrita antes de la Revolución, en la Cuba pos-revolucionaria. ${ }^{1}$

El exceso va mucho más allá de ser una apología y restitución de la figura de Virgilio Piñera y su obra. Paradójica y peligrosamente, máscara, actuación teatral y travestismo coinciden y se vuelcan hacia el espacio de la política para metaforizar el engaño y la simulación y convertirlos en alegoría política principal del periodo pos-revolucionario. Digo peligrosamente porque la alegoría pone en juego el lugar del teatro, y la relación que el teatro puede establecer entre su estética y la política, específicamente en el momento histórico que marca la disolución de las utopías ideológicas (la caída del muro del Berlín y el comienzo del Periodo Especial en Cuba). Este volcarse de lo estético en lo político, es decir, la lectura por la cual todo se convierte en teatro y el teatro pierde su organicidad para venir a definir los actos políticos, parece ser la razón de ser misma del texto, en un exceso alegórico que incluye también a la figura del homosexual y del travestí a quienes se busca legitimar y reinscribir en el cuerpo nacional.

Me interesa esa capacidad devoradora de la metáfora que se convierte en alegoría, el exceso de esa alegoría y la forma por la cual la crítica al texto hace cumplir de forma peculiar no tan sólo el significado más simple de la consigna de Electra Garrigó de "todo el mundo quiere ser engañado" (es decir, donde más que señalarse el engaño se responsabiliza al público por aceptarlo y se establece una equivalencia perfecta entre público teatral y polis) sino también el sentido aparente de los dos otros epígrafes de la novela. Tanto el epígrafe de Artaud de El teatro y su doble (1938), "Ante todo importa admitir que, al igual que la peste, el teatro es un delirio y es contagioso", como de Batman, "Todos usamos máscaras", parecen confirmar la clave alegórica que enlaza, sin quiebre posible, la estética teatral con la historia política que plantea la novela. Y, obviamente, el "teatro" lo invade todo. La vida política en la Cuba de 1989, en la antesala del Periodo Especial, está poblada de engaños forzados y voluntarios, de incesantes máscaras. La crítica de la novela subraya sobre todo la teatralidad del crimen principal, que en su resolución apoya el régimen revolucionario y parece anular la legitimación de la homosexualidad y la estética travestí planteada a lo largo

\footnotetext{
Buckwalter-Arias, en "Cross-dressing and Party Politics: On Leonardo Padura's Máscaras", hace ambos señalamientos: "Later in the same paragraph, Piñera says, "Maldigo mil veces mi timidez, o lo que sea, que me impidió salir por las calles remedando a un jefe griego, vestido con sábana y llevando una palangana en la cabeza a modo de caso' [8]. The proximity of the various images - the glorious Castro and the would-be ridiculous, outlandish Piñera, for example - cannot help but cause them to suffuse one another. Piñera appears to update for the Revolution his earlier thesis about the city's eagerness to be deceived, to be won over by the charismatic demagogue" (112). No concuerdo con Buckwalter-Arias en uno de sus argumentos principales, cuando dice "Máscaras immediately connects Piñera, then, to the theater's potential for deceiving the social collectivity" (111), y es precisamente en esa diferencia donde ubico la tesis de mi ensayo sobre Padura.
}

$111 \frac{\text { Revista Iberoamericana, Vol. LXXXV, Núm. 269, Octubre-Diciembre 2019, } 1155-1170}{\text { ISSN 2154-4794 (Electrónico) }}$ 
de la obra. ${ }^{2}$ El travestismo teatral único de Alexis entra en el escenario político para provocar el crimen y revelar la máscara continuada de su padre Faustino, quien accedió al poder después de la Revolución por medio de la falsificación de unos documentos destinados a comprobar su participación activa en contra del gobierno de Batista. Es decir, Faustino es, sin lugar a dudas, un "falso comunista" que arriesga y compromete los ideales del Estado con su "travestismo". La restitución final es así, en esta lectura, la restitución del Estado. Y a través de ese contagio "teatral" se revela también el teatro de la vigilancia panóptica aceptada por los vigilados: Maruchi, vestida de secretaria del mayor Rangel, es en realidad una informante del Estado destinada a descubrir claves inexistentes de corrupción policial. Sus acciones culminarán con el despido de Rangel, director de la Central de policías, quien, a diferencia de Faustino, es inocente, como sostendrá Mario Conde hasta el final de la tetralogía. Es decir, el teatro revela al falso comunista y también lo inventa en un juego que se encuentra a tono con la crítica posible en contra del régimen al momento de la publicación de la novela (1997).

El "teatro" le pertenece a todos en su contagio. Y lo cierto es que la estética travestí abarca una alegoría totalizadora que confirma el mismo Leonardo Padura en su entrevista con Epple: "Es una novela de homosexuales, de máscaras, centrada en ese fenómeno del travestismo moral que se ha vivido en Cuba en este tiempo, en que las personas dicen algo y piensan otra cosa, obligadas por las circunstancias" (58). Ese desplazamiento del travestismo al plano metafórico que deviene alegoría abarca al mismo Mario Conde, escritor forzado a abandonar su obra y a esconderse tras la máscara de policía, tal como confirma el propio Alberto Marqués al final de la obra después de leer el cuento que acababa de escribir Conde: "Es usted un hombre sorprendente, amigo señor policía. Tanto que ahora creo que usted es un falso policía. Es como otro tipo de travestimiento, ¿no?’ (217). El travestismo parece traicionarse a sí mismo en un deslizamiento que podría leerse, como denuncian muchos críticos, como una insuficiencia, comprometida en una representación política demasiado abarcadora.

Hay otro Padura en Máscaras, o hay otra lectura de la máscara, el travestismo y el gesto teatral de Piñera en Padura que exige quebrar el velo del exceso alegórico para centrarse en los gestos como medios sin fin. El término "medio como su propio fin" (73) aparece en la novela para hablar del travestismo y utilizarse como metáfora de la teatralización y el uso de máscaras en sus distintos niveles a lo largo de toda la

\footnotetext{
2 Así lo resume Buckwalter-Arias en su ensayo: “As occurs in 'El lobo, el bosque y el hombre nuevo', then, an incipient sexual identity politics is sacrificed to a more encompassing political allegory [...] The mask metaphor implies that like his son, Faustino transformed himself into something he never was or could be - a genuine, committed revolutionary. Apparently, then, beneath the masks there really are fixed identities - deep down people really are simply male or female, for example, committed revolutionaries or mere opportunists. To imagine otherwise is to open the political field to posers and frauds" (148).
} 
novela. Mario Conde, cuya profesión depende de la búsqueda de fines, cree entender que en el caso del travestismo, los medios no se utilizan para llegar a un fin específico, sino que son en sí mismos el fin, y que ese fin es la desaparición. Y, de hecho, ese desplazamiento del enfoque del travestí del fin a los medios es necesario en el acto de lectura de la tetralogía policial de Mario Conde. En una lectura simple, le permite al detective resolver el crimen y revelar también las causas y los efectos de una Cuba cuya historia puede explicarse dentro de una lectura "teatral". La lectura que propongo sugiere ir más allá de esa lectura, eliminar provisionalmente los "fines que provocan los medios" ( $\sin$ negarlos), para detenernos en los gestos mismos. Extraigo este término del ensayo de Agamben "Notas sobre el gesto" en Medios sin fin (2001):

El gesto es la exhibición de una medialidad, el hacer visible de un medio como tal. Hace aparecer el ser-en-un-medio del hombre y, de esta forma, le abre la dimensión ética. [...] así en el gesto lo que se comunica a los hombres es la esfera no de un fin en sí, sino de una medialidad pura y sin fin [...] El gesto es, en este sentido, comunicación de una comunicabilidad. No tiene propiamente nada que decir, porque lo que muestra es el ser-en-el-lenguaje del hombre como pura medialidad. (54-55, énfasis en el original)

Sostengo para la tetralogía de Padura una teorización del gesto más allá de, o quizá detrás de la lectura alegórica de la máscara y el travestismo en la que mayormente se concentra la crítica, utilizando los gestos de Electra Garrigó como punto de partida. Esta lectura que propongo exige leer ciertos gestos de Electra Garrigó como medios sin fin, articulándolos a través de la teorización del travestí en la obra de Sarduy La simulación (1982), que aparece también no tan simulada en la novela, y de la especificidad del lenguaje teatral avocado por Artaud en El teatro y su doble más allá del epígrafe citado. Es decir, detrás del exceso de citas donde la intertextualidad produce una serie de discursos a través de los textos, ${ }^{3}$ el enigma por resolver es la identificación del punto de articulación entre ellos. Padura mismo parece forzar ese enlace o lectura combinada entre gesto teatral y travestismo como clave de lectura:

El libro trataba de dar explicaciones filosóficas a aquella contradicción: el problema, creía entender el Conde, no era ser, sino parecer; no era el acto, sino la representación; ni siquiera era el fin, sino el medio como su propio fin: la máscara por el placer de la máscara, el ocultamiento como verdad suprema. (Máscaras 73)

La cita, es cierto, es una explicación del texto de Recio que es y no es el texto de Severo Sarduy, La simulación; sin embargo, a mi ver se trata, a través del texto de

3 Para un excelente estudio reciente del juego intertextual en esta obra de Padura, y los diálogos que suscita, ver "Transposed Words: Mapping Intertextuality in Leonardo Padura Fuentes' Máscaras", de Ángela Dorado Otero en The Dialogic Aspects of the Cuban Novel of the 1990s (2014). 
Sarduy, de explicar el concepto mismo de representación escénica (es decir, la razón de ser del teatro) a través de la representación realizada por la figura del travestí. Se trataría entonces de forzar una lectura desde la inflexión entre gesto teatral y travestismo, recordando siempre que uno y otro son campos diferenciados, y buscar desde allí otra relación entre el gesto teatral, la historia y la política.

Alberto Marqués resume para Conde el ensayo que sobre el travestí escribe su amigo Recio, titulado "El rostro y la máscara" (57). La definición del travestí que aparece en la novela es, casi punto por punto, la definición que aparece en la primera parte del ensayo de Severo Sarduy "La simulación": "En su disertación travéstica el Marqués mencionó tres actitudes posibles de los transformistas: la metamorfosis como superación del modelo, el camuflaje como forma de desaparición, y el disfraz como medio de intimidación" (57). ${ }^{4}$ Habría que completar que la desaparición detrás de la máscara, en el ensayo de Sarduy, lleva consigo una "pulsión letal” (14), es decir, un revelar para morir en la desaparición. Para propósitos del policial, Mario Conde resuelve su caso con las dos últimas "actitudes", dejando pasar por alto la primera, donde el travestí accede a los gestos de su modelo, los estudia, los incorpora, los enaltece y los supera por medio de un proceso de saturación. Pero para la relación del teatro con el travestismo, el mimetismo más allá del original es justamente lo que establece la equivalencia entre travestismo y teatro.

Esta idea aparece como uno de los puntos de partida en el ensayo de Ángela Dorado Otero:

Padura, however, points out the theatrical nature of the transvestite. In Máscaras the transvestite becomes the artist, the ideal actor par excellance; the transvestite is the artist whose artistic work appears to be his own body. El Marqués explains to Conde how he combines the idea of transvestism with the theatre: "Una apariencia. Una mascarada. Allí había estado la esencia misma de la representación, desde que las danzas rituales se transformaron en teatro, cuando surgió la conciencia de la creación artística: el travesti como artista de sí mismo" [...] As Butler writes, "That the gendered body is performative suggests that it has no ontological status apart from the various acts which constitute its reality". (57)

\footnotetext{
4 Leamos el texto de Sarduy: "El travestí humano es la aparición imaginaria y la convergencia de las tres posibilidades de mimetismo: el travestimiento propiamente dicho, impreso en la pulsión ilimitada de metamorfosis, de transformación [que] no se reduce a la imitación de un modelo real, determinado, sino que se precipita en la persecución de una irrealidad infinita, y desde el inicio del 'juego' aceptada como tal, irrealidad cada vez más huidiza e inalcanzable [...] hasta sobrepasar el límite, yendo más allá de la mujer, [...] pero también el camuflaje, pues nada asegura que la conversión cosmética -o quirúrgicadel hombre en mujer no tenga como finalidad oculta una especie de desaparición, de invisibilidad, d'effacement y de tachadura del macho en el clan agresivo [...] anulación que comunica con la pulsión letal del travestí y su fascinación por la fijeza a su vez fascinante; finalmente la intimidación, pues el frecuente desajuste o la desmesura de los afeites, lo visible del artificio, la abigarrada máscara, paralizan $o$ aterran $[\ldots] "(14)$.
}

$111 \frac{\text { Revista Iberoamericana, Vol. LXXXV, Núm. 269, Octubre-Diciembre 2019, }}{1155-1170}$ 
Dorado Otero comienza con esta equivalencia para luego continuar su análisis sobre los cambios en la definición del travesti y el travestismo entre Sarduy y Padura. Por un lado, le interesa extender el concepto del travestismo a la escritura misma de la novela (59-61) y, por otro, quiere explorar la definición misma del travestí, señalar que tanto Sarduy como Padura asumen una postura o cultura tradicional sobre el travestí que ya se ha rebatido. ${ }^{5}$ Es decir, observar el travestismo fuera del eje teatral en que específicamente lo coloca el texto. Mi interés es precisamente quedarme en la equivalencia teatral para volver al teatro como espacio y solucionar un acertijo, no para traer el teatro a la ficción narrativa o ubicar la figura del travestí en la historia.

La primera parte del ensayo de Sarduy concluye con una clave que puede ayudarnos a explicar, no tan sólo la gestualidad del travestí en su proceso de superar al modelo, sino también el concepto mismo de ciertos gestos teatrales que nos ayudarían a explicar la presencia de Electra Garrigó en Padura. Detrás del modelo copiado, es decir, detrás de los gestos de ese modelo, Sarduy reconoce el vacío y la nada:

A partir de esta nada y en función de ella, más presente cuanto más intensas son las imitaciones, más logrados los camuflajes, más exactas las analogías y usurpaciones del modelo, deben de leerse los fenómenos que aquí enumeramos, los cuales, a su vez, no son más que la teatralidad y saturación máxima, vistos desde la vacuidad inicial, de todos los otros. (20)

Teatralidad y saturación máxima de los gestos, que se sostienen en un vacío de significación, definen el sentido de los cuerpos y sus movimientos en la obra de Piñera, y la disolución de la figura de Electra en pura materia sin cuerpo. Nos dice María Zambrano sobre Electra Garrigó en una nota corta que escribió en 1948 para Prometeo:

La Tragedia griega tiene la virtud de ser algo así como el eje cristalino, en torno al cual, los occidentales seguimos haciendo girar nuestros últimos conflictos. Su íntima unidad se refleja en cada época de modo adecuado a la contextura de ese espejo cambiante que es la conciencia humana. Y es de notar que en los días que atravesamos, más que en ningunos otros, se recurre a la Tragedia griega como a un asidero último para expresar lo que parece ser más contrario a ella: los conflictos de la conciencia moderna. $[\ldots]$ ¿Cómo explicar la recurrencia insistente? Tal vez por esa misma condición de pasividad ante nuestros propios conflictos [...] Y así, la "Electra Garrigó" del poeta Virgilio Piñera presenta en su centro mismo, en la protagonista

5 “[...] On the other hand, I believe that Sarduy and Padura repeat a traditional view of transvestites. Both assume that transvestites want to erase any trace of masculinity, and that because of the hyperbole of the artifice the transvestite fails to become a woman and fails to conceal his male body. However, this traditional view of transvestism has been eroded by theoretical studies, for example Butler's and Gaber's" (62).

$111 \frac{\text { Revista Iberoamericana, Vol. LXXXV, Núm. 269, Octubre-Diciembre 2019, } 1155-1170}{\text { ISSN 2154-4794 (Electrónico) }}$ 
que le da nombre, más que un personaje, un vacío: el vacío de la conciencia "apática". (La Cuba Secreta 115, énfasis mío)

Si la tragedia clásica es un eje en torno al cual gira cada nueva acumulación de sentido, los personajes de Electra Garrigó entran en escena con el conocimiento de la propia representación de esa acumulación, de la repetición de gestos trágicos en un espacio que ahora toma por sentado el propio vacío, sugerido en gran parte por la ausencia de los dioses. Ese conocimiento establece entonces una doble demanda: la demanda de reconocer en el gesto la acumulación y la saturación, la teatralización del sentido, y la demanda de poder realizar una ruptura de la acumulación para ver el gesto como pura medialidad y lograr así otra lectura de la historia. Ambas demandas se confirman en el monólogo de Electra que inicia el segundo acto de la obra. Electra hace un llamado a los no dioses: “¿Dónde estáis, vosotros, los no dioses? ¿Dónde estáis, repito, redondas negaciones de toda divinidad, de toda mitología [...]?" (Piñera 16). Su llamado parte del conocimiento de su propia teatralidad: “¿Oye alguien la campanilla del ujier apelando a un juicio final que no se producirá?" (16). Y ante esa ausencia que niega el fin como objeto, Electra coloca todo el sentido, no en el fin, sino en el medio, en el gesto mismo de girar y en la ruptura del camino, de la direccionalidad del gesto hacia un fin:

¡Electra! ¡Electra giratoria! ¡En acecho, Electra! (Pausa) No avanzo, giro, siempre en el sentido de la luz. ¡Formas de ella, procuradme el camino y la frente que debo aniquilar! [...] ¡Atrás fantasmas de los antiguos dioses! ¡Dioses de nada con ojos de nada! Vais a caer en el centro de esta luz, y giraréis eternamente como la parte de un todo que no se compadece nunca de sí mismo. (17)

Electra, más que un personaje, es la consciencia de la representación del gesto puro. Y frente a ella, los demás personajes revelan su conciencia desde la lucha entre su emplazamiento histórico y su emplazamiento trágico. En esta versión de la tragedia griega, Agamenón aparece borracho en escena vestido con sábanas y con una palangana en la cabeza a modo de jefe griego, para revelar esa escisión entre personaje trágico y personaje histórico: “¿Es que nunca podrás contemplarme en el papel de Agamenón, rey de Micenas y Argos [...] He querido oscuramente una vida heroica, y soy sólo un burgués bien alimentado" (19). Y aunque Clitemnestra prefiere, en lugar de perderse en la actuación de un destino trágico, la "vida": "¡En cuanto a mí, confieso que prefiero la vida misma!" (18), Electra le recuerda que todo su esfuerzo no es sino pura simulación: "Lo sé todo; no comprendo tu simulación. Sería inútil" (20). Clitemnestra existe tan sólo como personaje, no puede preferir "la vida misma" en su no ser. Curiosamente, es en el gesto mismo de girar, igual que Electra Garrigó, donde encontrará Clitemnestra su fuerza para darle muerte a Agamenón Garrigó, es decir, para resolver su teatralidad: 
“(Da dos vueltas). Así, este girar me anima. Lo veo todo rojo. Me da fuerzas. [...] ¿Qué debo hacer, Electra, qué debo hacer? Electra: Obrar. Clitemnestra: (Girando de nuevo.) Sí, obrar, obrar rápidamente" (22). El valor del personaje de Electra no se encuentra entonces en su propia acción sino en ser gesto puro que pulsiona los gestos y las acciones de los otros y, al hacerlo, los revela. A diferencia de la conclusión a la que llega María Zambrano en su nota, quien nos dice que "La conciencia trágica es una de las luminosas profecías del Dios verdadero" (La Cuba secreta 117), es en la conciencia y la coincidencia de la saturación del gesto y del vacío donde terminan encontrándose la agencia y la articulación del significado en Electra Garrigó.

Electra Garrigó se afirma y confirma el sentido mismo del teatro en la conciencia de una representación pura que, saliendo del texto teatral, va más allá de él. Su sentido se encuentra en el teatro, es decir, en el momento de su representación. Para decirlo de otro modo, el texto teatral plantea su propia exégesis, nombra a la representación misma como el lugar del sentido. Plantea su propia consciencia y emplazamiento histórico y dirige el sentido del teatro hacia la representación. No existe entonces para el teatro una esencia estable, la esencia se produce en el momento mismo de la representación, en los gestos de la representación en su momento. Y, como nos dice Alan Badiou, es en este momento donde puede encontrarse la ética del teatro:

En la escena el actor exhibe la evaporación de toda esencia estable. La consistencia de los signos corporales y vocales con los cuales se vanagloria sirve ante todo para establecer, para sorpresa y deleite, que nada coincide consigo mismo. La ética de la actuación es la de un escape, podría decirse "escaparse a duras penas". En especial, el actor opera contra toda teoría natural de las diferencias y en particular de la diferencia de los sexos. Vuelve artificial aquello que creemos que es lo más evidentemente dado, combina lo que imaginamos desde siempre separado, separa eso cuya unidad parecía adquirida [...] Un espectáculo teatral es, en cada velada, una inauguración de sentido. (111-12)

Se trata entonces de un ser en el teatro que existe sólo en función de su representación y en Electra Garrigó, como veremos, el personaje de Electra se configura como la representación de esa esencia inestable, de esa esencia que no es sino representación de la nada.

Hablamos también del gesto como un lenguaje al límite en consonancia parcial con la teoría del lenguaje de los gestos de Antonin Artaud. El espacio teatral, nos dice Artaud, es un espacio tangible, físico, que necesita ser llenado y al que debe permitírsele hablar su propio lenguaje concreto.

Afirmo que la escena es un lugar físico y concreto que exige ser ocupado, y que se le permita hablar su propio lenguaje concreto. Afirmo que ese lenguaje concreto, destinado a los sentidos, e independiente de la palabra, debe satisfacer todos los

$111 \frac{\text { Revista Iberoamericana, Vol. LXXXV, Núm. 269, Octubre-Diciembre 2019, } 1155-1170}{\text { ISSN 2154-4794 (Electrónico) }}$ 
sentidos; que hay una poesía de los sentidos como hay una poesía del lenguaje, y que ese lenguaje físico y concreto no es verdaderamente teatral sino en cuanto expresa pensamientos que escapan al dominio del lenguaje hablado [...] Me parece urgente determinar qué es ese lenguaje físico, ese lenguaje material y sólido que diferenciaría al teatro de la palabra. (42)

La relación de Artaud con Máscaras, en una primera lectura, parece ser correctiva. Es decir, la puesta en escena de Electra Garrigó que configura Alberto Marqués en Máscaras, tal como se la explica a Mario Conde, conlleva un ajuste de la teoría de lenguaje teatral de Artaud. Es cierto que, igual que Artaud, Alberto Marqués busca sobre todo

la gestualidad que quería imponer a los actores, maquillándolos como máscaras griegas pero con caras muy habaneras, de blancos, mulatos y negros habaneros, tratando de que la máscara los mostrara y no los ocultara, que los revelara interiormente y no velara esa espiritualidad trágica y a la vez burlesca que quería buscar como esencia de una cubanía en la que Virgilio Piñera fungía como máximo profeta [...]. (Máscaras 165)

Sin embargo, inmediatamente después añade:

Comentaba que por eso también debía ayudarme mucho con la palabra, y no pretender, como el pobre Artaud, buscar un lenguaje escénico sólo apoyado en signos o gestos activos y dinámicos, porque uno de los rasgos más visibles de la cubanía es nuestra incontenible propensión a no cerrar la boca. (165)

Estos comentarios tienen para mí, desde la lectura de Electra Garrigó, la fuerza de un velo o acertijo en lugar de una corrección que debe de ser aceptada palabra por palabra como indiscutible manifiesto artístico. De hecho, el juego/pugna entre gesto y palabra pueden verse como posible dispositivo creativo para enlazar la obra de Piñera con la obra de Padura. Esa pugna aparece ya inscrita en la obra de Piñera. Antes de finalizar el primer acto, Clitemnestra silencia a sus hijos, quienes juegan verbalmente a convertir metáforas en gestos, ${ }^{6}$ diciéndoles: “iBasta de locuras! Somos humanos, y

6 El diálogo entre Electra y Orestes juega con la saturación de la metáfora para animalizar a los personajes, subrayando en el proceso la pérdida misma del lenguaje en su saturación y el avance del gesto como gesto:

ELECTRA. Yo, en cambio, soñé anoche que una yegua asesinaba a su semental dándole a oler un perfume chino...

ORESTES. ¡Oh, los relinchos...! Siempre quise ser un garañón. ¿Por qué no pedimos ser convertidos en una tropilla de caballos?

ELECTRA. Tienes razón. Me gustaría ser una yegua para sentarme en mi palco de la opera dándome aire lentamente con un abanico de plumas.

$111 \frac{\text { Revista Iberoamericana, Vol. LXXXV, Núm. 269, Octubre-Diciembre 2019, }}{1155-1170}$ 
no podremos, no, no podremos despojarnos de las palabras ni de los nombres!" (11). Es decir, imposible eliminar el lenguaje verbal (las palabras) o las marcas de la historia occidental y su cultura (los nombres). Sin embargo, la farsa/pantomima que sobreviene inmediatamente después, donde Clitemnestra proporciona la voz para las cuatro actrices negras que en silencio escenifican la muerte de Clitemnestra, comienza con la escisión total de las palabras y el movimiento. Clitemnestra, "completamente rígida" como nos dice la dirección escénica, declama: “¿Por qué me detengo? ¿Por qué no avanzo? ¿Por qué abro tanto la boca?" (11). Clitemnestra cumple con su "incontenible propensión a no cerrar la boca", mientras las camaristas cumplen, con gestos saturados de ironía, ${ }^{7}$ la muerte de la madre por el sufrimiento de la pérdida de su hijo Orestes Garrigó. Y si inicialmente parece triunfar la palabra inmóvil sobre los gestos mudos, es precisamente a manos de estos mismos cuerpos sin voz que Clitemnestra muere "verdaderamente" al finalizar la obra, cuando las camaristas le traen la fruta envenenada. ${ }^{8}$ Los gestos sin palabras terminan siendo la ruina de Clitemnestra.

No podemos, sin embargo, reducir la obra de teatro simplemente a una alegoría política del poscolonialismo inscrita en la pugna entre los gestos teatrales y las palabras. No podemos leer la secuencia de esos gestos únicamente como la acumulación que lleva inevitablemente a la acción, a la eliminación de las figuras en las que descansa el poder. La misma Electra lo subraya irónicamente después del asesinato de Agamenón, cuando dice: "No me importa la ley [...]" (23). Y el Pedagogo, por su parte, analiza la muerte de Agamenón como un simple hecho, desnudo de dialéctica y de explicación

ORESTES. Mientras, yo galoparía por el escenario pisoteando la cabeza enjoyada de la primadona (10-11).

¿A quién quiere Orestes hacerle esa petición de ser convertidos en una tropilla de caballos? ¿Se trata de un actor en busca de un nuevo rol, una nueva metáfora que asumir? Por otro lado, en esa transposición o desplazamiento metafórico, ¿no podríamos decir que se elimina la distinción entre actor y público? ¿Dónde se encuentra el director?

7 La ironía se expresa en términos de un movimiento giratorio con pérdida de visión, en la escenificación del juego popular de la gallinita ciega: "Las camaristas se ponen a dar vueltas alrededor del lecho, simulando burlonamente el juego de la gallina ciega" (11).

8 Ver la introducción de Sarah Townsend a la traducción de Electra Garrigó, en Stages of Conflict. A Critical Anthology of Latin American Theater and Performance. Su comentario sobre este momento escénico es de particular importancia: "Inspired by the nonspeaking slaves in Sophocles's play, they underscore the role of Western theater in establishing a cultural hierarchy whose terms are set by the white elite. Clytemnestra and Agamemnon seek to purge their fears and control reality by representing it, so they order their servants to 'die' in their place. When Electra applauds the pretend death of her mother's double, the queen boasts, 'While that Clytemnestra doesn't move, look at this one who moves and circulates like a menacing draft of air.' Yet the two monarchs are ultimately the victims of their own tragic framework. The black actresses who enact Clytemnestra's death at the beginning of the play turn out to be the agents of her demise in their second and final appearance onstage when they place before her the deadly fruit" (175-76). 
policial. ${ }^{9}$ Los gestos, los movimientos, el girar continuo en la obra teatral que repite y modifica, si bien son y se conocen como el producto de la historia y la cultura, se señalan a sí mismos absurdamente como reiteración y acumulación, como saturación sin avance. El texto se transforma en Electra, pero en una Electra que, como vimos al inicio, es sólo una saturación de gestos, que al final se resuelve en "fluido" y abarca toda la "materia", hasta que todos los objetos se vuelven Electra. La "puerta Electra" al final de la obra, "No abre ningún camino, tampoco lo cierra" (38). Se trata, me parece, de una nada sustancial que va más allá de un concepto de identidad. ${ }^{10}$

Lo que sí podemos hacer es ver, en esta pugna entre los gestos y movimientos por un lado, y las palabras por otro, una nueva clave de lectura para la historia y la cultura, clave que, a mi ver, tomó Leonardo Padura de Electra Garrigó para narrar el relato y la historia en Máscaras. Es allí donde se enlaza el gesto teatral con el gesto travestí. En un primer nivel, es esencial regresar al concepto mismo de teatralidad, y recordar que Alexis Arayán, al colocar la hoja de la Biblia con la transfiguración de Cristo en el volumen de la obra teatral de Piñera, está señalando su propio acto de transfiguración no como un acto de identificación (una forma de revelarse a sí mismo en el acto travestí) sino como una representación teatral en la clave Piñera, que ahora debemos de entender de otra manera. El texto repite una y otra vez que Alexis no tiene tendencia travestí. $\mathrm{Su}$ acto tampoco trata del travestismo como metáfora para el regodeo en el engaño político que asumen todos los personajes de la novela de una forma $u$ otra en uno u otro momento del texto. Se trata literalmente de una representación teatral a la cual se le añade la clave travestí y en la cual el autor, Alexis, rescribe también el texto de Electra Garrigó para provocar su propia muerte y revelar el engaño político de su padre. El que lo haga con un acto de travestismo señala, de forma saturada, al teatro mismo como forma y al travestí como parte de la figuración teatral, como la representación de la figuración misma y la actuación, estableciendo una consonancia entre el texto de Electra Garrigó - que afirma que es sólo en la singularidad de la representación donde existe la esencia del teatro-y la definición sobre el travestí provista por el ensayo "El rostro y la máscara”. Es, ciertamente, una articulación peligrosa en muchos niveles,

9 PEDAGOGO. (Levantando una mano.) ¡Pero no, Orestes, no se trata, en este caso, de una fuerza mayor que opone una resistencia igualmente máxima. No se trata, repito, del material resistente que informa a esa fuerza. [...] ¡No, no, no Orestes! Nada de pesquisas, ni una gota de Scotland Yard. Egisto es un consumado estrangulador. Eso es todo (25-26).

${ }^{10}$ Nos dice Badiou: "El teatro vehicula desde el origen un 'feminismo' esencial, que no tiene por fundamento la igualdad, sino la nada sustancial de lo que marca la diferencia de los sexos, el carácter puramente lógico, y transparente, de esta marcación. O aun, si se quiere, que la mujer no existe, puesto que un hombre o una mujer, actor o actriz, se basa en producir sus signos o insignias. Esto por sí solo puede explicar que el teatro de los griegos presente figuras femeninas potentes, en una sociedad en la cual las mujeres están políticamente ausentes, socialmente confinadas y filosóficamente mantenidas en un bárbaro segundo plano" (105).

$111 \frac{\text { Revista Iberoamericana, Vol. LXXXV, Núm. 269, Octubre-Diciembre 2019, }}{1155-1170}$ 
porque se juega desde una definición de género y sexualidad para definir el gesto teatral como representación pura y el sentido de ese gesto en el "punto singular" del momento de actuación, en una manera donde la definición misma del travestí se pone en peligro.

En la elaboración de este ensayo, comenzado en 2013, me encuentro ahora con el texto de Badiou que parece comprobar punto por punto la articulación que intuí en la novela de Padura entre travestismo y gesto teatral. Cito:

Si el texto de teatro es tal que sólo la excepción de una representación lo hace existir, si como texto de teatro está sometido, en cuanto a su totalización propiamente teatral, al punto singular -y él mismo fuera del texto de la actuación [jeu], del instante de la actuación [jeu]-, entonces es legítimo decir que el teatro se escribe "no-todo", a diferencia del mundo compacto y autosuficiente que es el imaginario de la novela clásica. [...] Por lo demás se sabe que desde el sesgo del travestismo, de la inseguridad sexual, de la puesta en subasta del falo en las farsas, el teatro promociona esta latente irrisión del glorioso "Todo" de la masculinidad. [...] No creo en absoluto en el tema del actor andrógino; por el contrario, nada hay más distinto en el teatro que los hombres y las mujeres. Actores y actrices presentan la diferencia, la consolidan, pero esto es también para que la imitación circule de tal manera que este dado sea acentuado, por una parte, y descentrado y devuelto, por la otra. Una gran apuesta [enjeu] del teatro [...] es proponer la tesis siguiente: los dos sexos difieren, de forma radical, pero no hay exactamente nada sustancial en esa diferencia. El teatro nos introduce por su actuación [jeu] a este primer punto de la ética: sepan ustedes que ninguna diferencia es natural y, para comenzar, la que instituye que haya hombres y mujeres. (88-104)

Quiero extraer dos elementos de esta cita. Uno, que ya conocemos en el Badiou de "La danza como metáfora para el pensamiento", es la posibilidad del gesto y el movimiento -en el teatro y la danza- de ser sin marcas históricas y culturales. El género es una de esas marcas que, a pesar de su diferencia radical, demuestra su "no-ser" en el acto de la representación. Esto lo explica Badiou a lo largo de su Rapsodia para el teatro y lo lleva a su límite con la presentación del travestí como el extremo de la ruptura en la representación. El otro elemento tiene que ver con el concepto mismo de la representación y su relación con la historia y el tiempo: el gesto y la actuación teatral es lo que enlaza la historia del texto que se repite (y que suma con cada repetición más historia sin eliminar la anterior) con la singularidad de su propio momento de ejecución y, por ende, con ese presente. Es decir, como nos dice Badiou citando a Vitez: "la función real del teatro es orientarnos en el tiempo, decirnos dónde nos hallamos en la historia" (133). En el caso de esta novela de Padura, a mi ver, la articulación teatral es la que proporciona el soporte principal del texto y es desde allí que podemos quizá entender la fórmula de Artaud del contagio teatral.

$111 \frac{\text { Revista Iberoamericana, Vol. LXXXV, Núm. 269, Octubre-Diciembre 2019, } 1155-1170}{\text { ISSN 0034-9631 (Impreso) }}$ 
Tanto en Electra Garrigó, como en Máscaras, se accede a la saturación de los gestos para narrar la acumulación histórica que lleva, con facilidad, a una o varias lecturas alegóricas, a un sentido de continuidad y repetición en la historia. Ésta es la lectura fácil, que coincide también con la escritura poética de los gestos teatrales en Antonin Artaud, su necesidad de la posibilidad alegórica del cuerpo. ${ }^{11}$ Los gestos y movimientos en Electra Garrigó y en Máscaras demandan también la lectura de los gestos en sí mismos como ironía y ruptura, como un decir histórico, como la mejor manifestación abstracta de la historia en su momento de ser.

En Máscaras, esa lectura del gesto se realiza más allá de los gestos saturados del travestí, o del travestismo y la máscara en todas sus formas en la novela. Recordemos que cuando comienza la novela, ya se han cumplido los hechos. Mario Conde, escritor apócrifo dentro de la novela misma, utiliza este conocimiento de la saturación de los gestos para construir toda otra serie de gestos que podemos entender únicamente $a$ posteriori. La clave de esta lectura se encuentra al comienzo mismo de la novela, donde se vuelve descripción un gesto de Electra Garrigó que podría pasar desapercibido en la lectura o visualización de la obra teatral. "El calor es una plaga maligna que lo invade todo. El calor cae como un manto de seda roja, ajustable y compacto, envolviendo los cuerpos, los árboles, las cosas, para inyectarles el veneno oscuro de la desesperación y la muerte más lenta y segura" (Máscaras 13). Este gesto que da inicio a la novela repite el momento en Electra Garrigó cuando Electra toma su propio chal rojo para cubrir a Clitemnestra antes de que ésta le dé muerte a Agamenón (Piñero 21). Por otro lado, la descripción de Padura manifiesta el concepto mismo de disolución en puro fluido incontrolable, ya presente en la figura de Electra Garrigó. Recordemos cómo Egisto le dice a Clitemnestra: “¿Crees que se puede estrangular a un fluido?”

${ }^{11}$ La relación que establece Artaud entre la peste y el teatro se resuelve en su texto poéticamente. Y esto porque Artaud quiere producir una poética del teatro, y de sus lenguajes, que sostenga su razón de ser en virtud de su conformación como figura simbólica: "La peste toma imágenes dormidas, un desorden latente, y las activa de pronto transformándolas en los gestos más extremos; y el teatro toma también gestos y los lleva a su paroxismo. Como la peste, rehace la cadena entre lo que es y lo que no es, entre la virtualidad de lo posible y lo que ya existe en la naturaleza materializada. Redescubre la noción de las figuras y de los arquetipos, que operan como golpes de silencio, pausas, intermitencias del corazón, excitaciones de la linfa, imágenes inflamatorias que invaden la mente bruscamente despierta. El teatro nos restituye todos los conflictos que duermen en nosotros, con todos sus poderes, y a esos poderes nombres que saludamos como símbolos; y he aquí que ante nosotros se desarrolla una batalla de símbolos, lanzados unos contra otros en una lucha imposible; pues sólo puede haber teatro a partir del momento en que inicia realmente lo imposible, y cuando la poesía de la escena alimenta y recalienta los símbolos realizados" (31). En la obra de Padura, esta capacidad poética de los gestos se convierte en el velo que "resuelve" la historia, que resuelve el policial. Es también la articulación alegórica que "explica" la historia de Cuba en el comienzo del Periodo Especial. Pero, como sabemos, el policial es únicamente un pretexto. Como diría Oscar Wilde en "La decadencia de la mentira": "Más que un espejo, es un velo. Tiene flores que desconocen todas las florestas y pájaros que ningún bosque posee. Hace y deshace muchos mundos, y puede quitar la luna del cielo con un hilo rojo" (Wilde 15).

$111 \frac{\text { Revista Iberoamericana, Vol. LXXXV, Núm. 269, Octubre-Diciembre 2019, }}{1155-1170}$ 
(35). Esa disolución a partir de la saturación de los gestos se convierte en Padura en la manifestación de la disolución de la historia en gesto puro: "El calor lo aplasta todo [...] como si su propósito fuera provocar el fin de los tiempos, la historia, la humanidad y la memoria..." (13). A partir de ahí, Mario Conde se convierte en un lector de gestos y confirma en cada lectura de cada gesto la demanda de una doble lectura, desde la acumulación que lleva al exceso y a la lectura alegórica, a la lectura de los gestos desde su propia medialidad, con la capacidad de mostrarnos una lectura de la historia en su momento. Ésta sería la posibilidad ética que plantea la novela de Padura. Para Mario Conde, la lectura de las especificidad de los gestos que parecen repetidos, pero no lo son, encapsula la función de leer el presente desde la historia y su repetición. Leído así, el travestismo se convierte en el énfasis del gesto como medialidad posible de lectura, como forma de proclamar esa medialidad antes y después de los fines históricos conocidos y reconocidos como fin en el policial. En Máscaras, además de los gestos saturados que ya hemos analizado, aparecen específicamente otros: la lectura del juegomovimiento de béisbol en la esquina de su casa o la lectura de los gestos de la criada que trabaja en la casa de Faustino Arayán. La lectura poética, alegórica, del travestismo en Padura, que nos da una explicación de la historia, es entonces el enorme velo que cubre el gesto mismo como condición única del presente. Esta demanda de una lectura del gesto y el movimiento en Padura, a mi ver, se la debe Padura a Virgilio Piñera, y anuncia una nueva propuesta de creación estética y política, donde la medialidad sea la escritura del presente histórico y político escondida detrás de la lectura alegórica. 


\section{BiBLIOGRAFÍA}

Agamben, Giorgio. Medios sin fin. Notas sobre la politica. Antonio Gimeno Cuspinera, trad. Valencia: Pre-Textos, 2001.

Artaud, Antonin. El teatro y su doble. Enrique Alonso y Francisco Abelenda, trads. Barcelona: Edhasa, 2001.

Badiou, Alain. Rapsodia para el teatro. Buenos Aires: Adriana Hidalgo editora, 2015. Bejel, Emilio. "Un-veiling Machismo." Gay Cuban Nation. Chicago: U of Chicago P, 2001. 169-96.

Buckwalter-Arias. "Cross-dressing and Party Politics: On Leonardo Padura's Máscaras." Cuba and the New Origenismo. Suffolk: Tamesis, Woodbridge, 2010. 111-51.

Dorado Otero, Ángela. "Transposed Words: Mapping Intertextuality in Leonardo Padura Fuentes' Máscaras." Dialogic Aspects of the Cuban Novel of the 1990s. Suffolk: Tamesis, Boydell \& Brewer, 2014. 47-98.

Epple, Juan Armando. "Entrevista (Leonardo Padura Fuentes)". Hispamérica 24/71 (1995): 49-66.

Fernández, Manuel, "La figura del mimo en Máscaras de Leonardo Padura Fuentes". Ciberletras (July 2002). <http://www.lehman.cuny.edu/ciberletras/v07/fernandez. html>. 13 enero 2013.

Fornet, Jorge. "La narrativa cubana entre la utopía y el desencanto". Hispamérica 32/95 (2003): 3-20.

Goethe, Johann Wolfgang von. "Women's Parts Played by Men in the Roman Theatre." Crossing the Stage. Controversies on Cross-Dressing. Lesley Ferris, ed. Londres: Routledge, 1993. 47-57.

Matas, Julio. "Vuelta a Electra Garrigó de Virgilio Piñera". Latin American Theatre Review (1989): 73-79.

Millares, Selena. "La subversión del logos en el teatro de Virgilio Piñera". Teatro: Revista de Estudios Culturales / A Jornal of Cultural (1997): 235-245. <http:// digitalcommons.conncoll.edu/cgi/viewcontent.cgi? article $=1123 \&$ context $=$ teat ro>. 2 enero 2013.

Padura, Leonardo. La cultura y la revolución cubana. San Juan: Editorial Plaza Mayor, 2002.

Máscaras. Barcelona: Tusquets Editores, S.A., 2009.

Paisaje de otoño. Barcelona: Tusquets Editores, S.A., 1998.

Pasado perfecto. Barcelona: Tusquets Editores, S.A., 2000.

Vientos de cuaresma. Barcelona: Tusquets Editores, S.A., 2001.

Piñera, Virgilio. Teatro completo. La Habana: Letras Cubanas, 2002.

Sarduy, Severo. La simulación. Caracas: Monte Ávila Editores, C.A., 1982.

$111 \frac{\text { Revista Iberoamericana, Vol. LXXXV, Núm. 269, Octubre-Diciembre 2019, } 1155-1170}{\text { ISSN 2154-4794 (Electrónico) }}$ 
Townsend, Sarah. Prólogo a la traducción de Electra Garrigó en Stages of Conflict. A Critical Anthology of Latin American Theater and Performance. Ann Arbor: U of Michigan P, 2008. 173-79.

Wilde, Oscar. La decadencia de la mentira (Observaciones). Librodot.com, s.a. $<$ http:// ww2.educarchile.cl/Userfiles/P0001\%5CFile\%5Carticles-106946_Archivo.pdf>. 13 enero 2013.

Zambrano, María. La Cuba secreta yotros ensayos. Madrid: Ediciones Endymion, 1996. Obras Completas, III. Barcelona: Galaxia Gutenberg, 2011.

Palabras clave: $\quad$ travestismo - simulación - teatro - Badiou - política

Recibido: $\quad$ agosto 2016

Aceptado: $\quad$ mayo 2017 